forestry. Documents that will be subsequently issued by the Canadian Council of Resource Ministers will include recommendations for action on abatement and control of pollution that should receive careful attention by the appropriate personnel and agencies of the Canadian forestry community.

V. J. NoRDIN

\title{
Are Canadian Financial Incentives For Graduate Study in Forestry Adequate?
}

Many non-monetary current and long-term consumer satisfactions can be derived from post-graduate education (Schultz, 1963) yet there are grounds for questioning the adequacy of present financial incentives for graduate study in Canada. Table 4 of Marshall (1964) indicated a highly variable and uncertain increase in annual income associated with education to the Master's or Doctorate level. Median 1963 earnings for those with a Bachelor's degree were reported as $\$ 8,050$, for a Master's degree as $\$ 8,400$, and for a Doctor's degree as $\$ 10,200$.

Figure 2 of the summary of 1964 earnings by Babcock, Marshall and Stewart (1966) also gave disturbing evidence that Canadian rewards for research and teaching have not been commensurate with the academic ability of those concerned. However, their figure 3 using median 1964 incomes by level of education and year of bachelor graduation showed substantial premiums for increased education for graduates of the decade 1941 to 1950. Median incomes for the 1945 year of bachelor graduation, or 20 years of experience, are given for both Canadian and American foresters and forest scientists in Table 1. Earnings of members of the Society of American Foresters in 1964 were reported by Evans (1965). Evans' conclusion that in the U.S.A. education "pays, and pays, and pays!" is abundantly confirmed by the data in Table 1 .

TABLE 1

Median 1964 Salaries for 1945 Year of Bachelor Graduation oR 20 YEARS EXPERIENCE

\begin{tabular}{|c|c|c|c|c|c|c|}
\hline \multirow{2}{*}{$\begin{array}{l}\begin{array}{l}\text { Degree held } \\
\text { or decile }\end{array} \\
\text { Upper decile }\end{array}$} & \multirow{2}{*}{$\frac{\begin{array}{c}\text { Median } \\
\$\end{array}}{14,500}$} & \multicolumn{2}{|l|}{$\begin{array}{r}\text { Canada } \\
\$\end{array}$} & \multirow{2}{*}{$\frac{\begin{array}{c}\text { Median } \\
\$\end{array}}{16,000}$} & \multicolumn{2}{|l|}{ U.S.A. } \\
\hline & & $+4,900$ & +51.0 & & $+5,400$ & +51.0 \\
\hline Doctor & 11,700 & $+2,100$ & +21.9 & 14,100 & $+3,500$ & +33.0 \\
\hline Master & 10,500 & +900 & +9.4 & 11,700 & $+1,100$ & +10.4 \\
\hline Bachelor & 9,600 & 0 & 0 & 10,600 & 0 & 0 \\
\hline No degree & 8,400 & $-1,200$ & -12.5 & 8,500 & $-2,100$ & -18.1 \\
\hline Lower decile & 7,000 & $-2,600$ & -27.2 & 8,000 & $-2,600$ & -24.5 \\
\hline Sources & Babcock & et al. $(1966$ & & Evans ( & $965)$ & \\
\hline
\end{tabular}

Premiums paid for 1966 U.B.C. forestry graduates with advanced degrees were similar to those reported for the older group shown in Table 1 . They were comparable to those reported by Schreiner (1966) for advanced degrees held by Canadians graduating in 1966. He listed salaries showing premiums 
of from 64 to 141 dollars per month for masters' degrees and from 135 to 164 dollars per month for the Ph.D.'s

Although it appears as if financial incentives for graduate study are increasing, two other factors should also be considered. First, holders of the M.F., M.Sc., or Ph.D. are generally in the upper decile of academic ability. Since the median group achieving the $\mathrm{Ph} . \mathrm{D}$. should have ranked in the upper 5 per cent of graduates in forestry and those obtaining the M.F. or M.Sc. in the upper 15 per cent it would not be unreasonable to expect that their salaries should reflect their superior academic ability. Yet the data of Table 1 indicate that even the median level of annual incomes for those holding the Ph.D. falls far short of the upper decile of 1964 salaries. Second, is the substantial extra cost of securing two to four years of post-graduate education. This must be added to the already considerable net sum of about $\$ 23,000$ (mostly income foregone) invested by each 1967 graduate of Canadian Faculties of Forestry in his five years of University education. Assuming that annual income foregone of $\$ 6,600$ is partially offset by income earned from fellowships, assistantships, or other sources which amount to $\$ 2,600$, each year of graduate study involves an investment of perhaps $\$ 4,000$. Then, without considering interest, the period needed to pay for an investment of $\$ 8,000$ in a two-year M.F. or M.Sc. program will be about 8 years. Because of the greater annual premium involved the investment in a fouryear $\mathrm{Ph} . \mathrm{D}$. program will also be recovered in about 8 years.

The intellectual satisfactions that arise from appropriate specialization in study of an interesting subject may themselves more than compensate an individual for the time, effort, and money invested in graduate study, yet attention should be drawn to financial aspects of education. The 1965 report of the Economic Council of Canada emphasized the need for Canadians to encourage education, as the soundest basis for sustained economic and cultural growth. Canadian forestry administrators should look at the rewards offered for superior education and ask if enough is being done to attract the best men and to hold them in research and in teaching.

J. H. G. SMITH

\section{REFERENCES Cited}

BABCOCK, H. M., J. E. MARSHALL and J. W. STEWART, 1966. C. I. F. Salary Survey 1965. For. Chron. 42(1): 108-17.

EVANS, T. C. 1965. Professional income of foresters-1964. Jour. For. 63 (9): 681-86. MARSHALL, J. E. 1964. Canadian Institute of Forestry Salary Survey Report-1964. For. Chron. $40(2): 279-87$.

SCHREINER, J. 1966. Golden spring for graduates in 1967. The Financial Post, Nov, 26, page 11.

SCHULTZ, T. W. 1963. The economic value of education. Columbia Univ. Press, 92 g. 